\title{
PENANGGULANGAN KEBIASAAN MENGHISAP JEMPOL PADA ANAK (STUDI LITERATUR)
}

\begin{abstract}
Nurhaeni
ABSTRAK

Kebiasaan buruk didefinisikan sebagai pengulangan stereotipik fungsi sistem mastikasi, yang berbeda secara kualitatif dan kuantitatif dari fungsi fisiologisnya. Kebiasaan buruk biasanya berlangsung secara diamdiam sehingga membuat anak tidak sadar bahwa ia sering melakukan hal tersebut. Kebiasaanpada awalnya dilakukan dalam keadaan sadar, tetapi pengulangan membuat turunnya kesadaran dan respon motorik. Akhirnya kebiasaan terbentuk sepenuhnya dan menjadi bagian dari rutinitas pikiran sehingga lebih susah untuk menghilangkan kebiasaan buruk tersebut. Kebiasaan buruk umum dilakukan anak dengan status psikologis normal, tetapi dapat juga terjadi pada anak dengan masalah perkembangan, kesulitan emosional, atau gangguan fisik.. Refleks menghisap muncul di sekitar usia kehamilan 29 minggu, dan merupakan salah satu kebiasaan yang dilakukan secara alami oleh $89 \%$ bayi di bulan kedua dan $100 \%$ anak pada tahun pertama usia. Apabila kebiasaan tersebut terus dilakukan dalam jangka waktu yang cukup lama dengan intensitas yang cukup, maka akan terjadi efek samping yang mempengaruhi kondisi gigi geligi dan lebih lanjut mempengaruhi penampilan seseorang. Tujuan penulisan ini adalah untuk mengemukakan akibat kebiasaan jelek menghisap jempol dan beberapa cara menanganinya. Penelitian ini menggunakan pendekatan deskriptif dan jenis penelitian yang digunakan adalah kepustakaan/ literature study. Metode pengumpulan data yang digunakan yaitu berasal dari sumber data sekunder seperti jurnal, buku, karya tulis ilmiah, skripsi, text book dan artikel ilmiah. Hasil penelitian ini didapatkan bahwa penanggulan kebiasaan menghisap jempol dapat dilakukan dengan cara Penanggulangan kebiasaan menghisap jempol pada anak perawatan psikologi, perawatan ekstra oral, dan perawatan intra oral.
\end{abstract}

Kata Kunci : menghisap jempol; penanggulangan, kebiasaan buruk

\section{PENDAHULUAN}

Dalam masa pertumbuhan, anak-anak sering melakukan kebiasaanburuk. Perhatian orang tua terkadang luput dari pengamatan yang seharusnya perlu diamati utamanya pada kebiasaan yang berkaitan dengan kesehatan gigi dan mulut pada anak. Kebiasaan buruk itu dapat berupa menghisap jempol, menjulurkan lidah, menghisap bibir, menggigit-gigit bibir, pipi atau kuku atau kebiasaan buruk lain (bernafas melalui mulut, bruxism). Salah satu kebiasaan buruk yang paling menonjol pada anak adalah kebiasaan menghisap jempol.( Putri, dkk, 2010)

Kebiasaan menghisap jempol dilakukan oleh $70-90 \%$ bayi, bahkanbayi diseberang belahan dunia sekalipun. Meskipun tidak pada semua bayi, bayi-bayi mempunyai insting untuk menghisap jempol pada bulan- bulan pertama kehidupannya, bahkan sejak bayi dalam kandungan. (Goenharto, dkk, 2016) Tindakan menghisap jempol masih dapat dikatakan wajar apabila terjadi pada anak usia di bawah dari 2 tahun. Namun, apabila anak di atas 2 tahun masih saja menghisap jempol maka ada kemungkinan anak tersebut mengalami gangguan psikologis seperti perasaan cemas, takut, kurang perhatian atau tidak percaya diri. (Giri, 2017). Hal lain yang perlu diingat yaitu alasan bayi menghisap jempolnya karena ia merasa lapar, tidak aman, merindukan kenyamanan seperti yang ia rasakan ketika dalam kandungan, atau ketika ia menghisap dari putting susu sambil dipeluk oleh ibunya. (Dewi, 2017)

Berdasarkan hasil Riset Kesehatan Dasar (Riskesdas) Nasional pada tahun 2018, prevalensi masalah gigi dan mulut didapatkan angka sebesar $57,6 \%$. Salah satu kelainan gigi dan mulut yang dijumpai pada masyarakat Indonesia adalah maloklusi. Maloklusi merupakan kelainan gigi yang menduduki peringkat ketiga setelah karies gigi dan penyakit periodontal pada masalah kesehatan gigi dan mulut di Indonesia dengan prevalensi yang sangat tinggi yaitu mencapai angka $80 \%$. Tingginya 
angka tersebut disebabkan karena masih rendahnya tingkat kesadaran perawatan gigi masyarakat Indonesia. (Adha, dkk, 2019)

Kelainan lengkung rahang dapat dihindari bila kebiasaan menghisap jempol dihentikan sebelum gigi depan tumbuh. Tapi bila kebiasaan berlanjut hingga gigi geligi campuran (masih ada gigi susu dan sudah ada gigi tetap) maka kelainan bisa terjadi sampai kepada maloklusi. Keparahan dari letak gigi geligi tergantung pada frekuensi (seringnya menghisap), intensitas (kekuatan menghisap), lamanya kebiasaan dan berapa tahun kebiasaan itu berlangsung. (Goenharto, dkk, 2016)

Untuk menghilangkan kebiasaan buruk tersebut, orang tua harus mencari penyebabnya dahulu. Apabila penyebabnya sudah diketahui, secara bertahap orang tua dapat menghilangkan dengan cara melakukan pendekatan psikologis pada anak, ataupun dengan menghentikan kebiasaan tersebut sebelum gigi permanen erupsi dan melakukan perawatan selama 4-5 tahun berikutnya. Mencegah atau menghentikan kebiasaan menghisap jempol sebelum menimbulkan kelainan yang menetap, merupakan suatu upaya mencegah terjadinya maloklusi. Perlu disadari adanya keanekaragaman sikap dan pendapat sehubungan dengan makna dan perawatan kebiasaan buruk pada anak. ( Hidayani, 2019). Oleh sebab itu penulis merasa perlu untuk membuat suatu kajian untuk mengemukakan akibat kebiasaan jelek menghisap jempol dan beberapa cara menanganinya.

\section{METODE PENELITIAN}

Penelitian ini menggunakan pendekatan deskriptif dan jenis penelitian yang digunakan adalah kepustakaan/ study literature. Metode pengumpulan data yang digunakan yaitu berasal dari sumber data sekunder seperti jurnal, buku, karya tulis ilmiah, skripsi, text book dan artikel ilmiah. Data yang dikumpulkan kemudian dipilah dan disajikan dalam bentuk naratif.

\section{HASIL DAN PEMBAHASAN}

Bayi yang baru dilahirkan tidak mempunyai gigi merupakan hal yang normal, walaupun benih sudah ada jauh pada saat bayi masih dalam kandungan. Kalsifikasi dari gigi sulung sudah ada sejak usia janin 4 bulan di dalam kandungan. Benihbenih gigi geligi sulung mulai berkembang pada umur embrio 6 bulan dalam kandungan. Biasanya bayi yang baru lahir belum membutuhkan gigi karena makanannya masih berupa ASI atau berbentuk cair. Gigi bayi sudah mulai diperlukan apabila bayi sudah mulai makan-makanan yang sifatnya padat, seiring dengan bertambahnya umur bayi, maka gigi-gigi susu satu persatu akan mulai tumbuh dengan berbagai tingkatannya. Tetapi adakalanya bayi yang baru dilahirkan sudah mempunyai gigi geligi insisivus bawah. (Savitri, 2020)

Penyebab gangguan perkembangan gigi geligi

1. Penyebab tidak langsung

Adapun faktor yang dapat mempengaruhi terjadinya kelainan pertumbuhan dan perkembangan gigi secara tidak langsung antara lain:

a. Faktor keturunan (genetik)

Faktor keturunan (genetik) dapat menyebabkan pertumbuhan dan perkembangan rahang dan gigi seseorang, seperti contoh orangorang di Afrika sana mempunyai bentuk rahang dan gigi yang ukurannya lebih besar. Maka, sebagian besar dapat menurun ke anak-anak mereka nantinya. (Pratiwi, 2013)

b. Faktor gangguan pada janin (congenital) Apabila dalam masa kandungan terjadi gangguan pada janin (congenital), misalnya kurangnya asupan gizi pada janin, maka dapat mengakibatkan terjadinya gangguan perkembangan dan pertumbuhan pada janin, termasuk juga pertumbuhan gigi dan rahangnya.

c. Gangguan keseimbangan kelenjar endokrin. Kelenjar endokrin sangat berpengaruh di dalam tubuh, karena hormon ini mengalir langsung ke dalam darah atau limfe danbanyak memodifikasi 
metabolisme dan pertumbuhan tubuh. Jadi, apabila terjadi gangguan keseimbangan endokrin maka proses pertumbuhan dan perkembangan juga terganggu.

2. Penyebab langsung

Faktor-faktor penyebab langsung terjadinya gangguan perkembangan gigi geligi yang tidak teratur adalah :

a. Gigi tidak ada/ gigi tidak tumbuh (missing teeth)

Adakalanya gigi seseorang tidak tumbuh. Gigi-gigi tersebut biasanya pada gigi incisivus pertama dan kedua, premolar kedua, molar ketiga rahang atas dan bawah. Apabila seorang anak mempunyai kelainan gigi yang tidak erupsi/hilang, pada lengkung gigi di dalam rongga mulutnya akan terbentuk ruangan kosong sehingga tampak adanya celah antar gigi. Karena premolar kedua lebih sering tidak terbentuk, maka sebelum mencabut gigi-gigi lain dianjurkan untuk memeriksa lengkap tidaknya gigi.

b. Gigi tambahan (supernumerary)

Kondisi gigi tambahan adalah kebalikan daripada gigi tidak tumbuh atau tidak ada. Gigi tambahan ini ditujukkan dengan tumbuhnya gigi dalam jumlah yang banyak dari pada normalnya. Apabila gigi tambahan ini tumbuh dalam lengkung gigi maka akan mengakibatkan gigi yang berjejal. Gigi tambahan ini lebih sering dijumpai diantara gigi incisivus kanan dan kiri rahang atas. Gigi ini berbentuk kerucut dan lebih kecil daripada gigi sebelahnya, yang dikenal dengan mesiodens. Gigi tambahan dapat ditemukan di manapun di dalam mulut. Kadang-kadang sebagai contoh misalnya pada gigi incisivus kedua atas atau bawah, mirip dengan gigi normal. Gigi ini dapat menyebabkan gigi berjejal sehingga harus dicabut sebelum memberi dampak gigi berjejal. (Fidya, 2018)

c. Gigi susu yang tanggal sebelum waktunya (premature loss)

Jika sudah waktunya, gigi sulung akan goyang akibat adanya tekanan dari gigi permanen dan lama kelamaan akan tanggal. Selanjutnya posisi gigi sulung ini akan tergantikan oleh gigi permanen. Apabila gigi sulung ini tanggal sebelum waktu gigi penggantinya erupsi, maka akan menimbulkan maloklusi.

d. Gigi sulung yang tidak tanggal meskipun gigi tetap penggantinya telah tumbuh (persistensi)

Kelainan ini merupakan kebalikan dari premature loss. Pada kelainan ini gigi sulung tidak tanggal meskipun gigi penggantinya telah erupsi sehingga gigi permanen penggantinya akan muncul diluar lengkung rahang dan tampak berjejal. Sebagai contoh, jika gigi incisivus sulung tidak teresorbsi normal, maka gigi incisivus permanen penggantinya akan bergeser kelingual atau kelabial. Gigi sulung yang persistensi juga dapat disebabkan karena gigi tersebut mengalami ankylosis yaitu gigi terfiksasi karena terjadinya fusi antara sementum dan tulang alveolar sehingga ligamentum periodontium menjadi rusak. Kadang-kadang akar gigi molar sulung mengalami ankylosis terhadap tulang alveolar sehingga gigi ini tidak akan erupsi. (Dentalosophy, 2020)

e. Bentuk dan posisi gigi yang tidak normal

Satu atau beberapa gigi tetap seseorang kadang-kadang tidak normal. Misalnya, pada gigi incisivus kedua rahang atas berbentuk konus/pasak, sehingga tampak lebih kecil daripada gigi incisivus kedua yang lainnya. Kondisi seperti ini akan membentuk ruangan kosong sehingga gigi terlihat bercelah. Ini menyebabkan oklusi gigi geligi menjadi tidak normal. Sedangkan posisi gigi yang tidak normal menunjukkan adanya perkembangan yang abnormal sehingga dapat terjadi maloklusi.

f. Ikatan otot bibir (frenulum labii) yang tidak normal

Apabila bibir atas seseorang ditarik keatas, akan tampak ikatan otot antara bibir dan gusi. Ikatan otot inilah yang dinamakan frenulum labii. Bila normal frenulum labii mempunyai daerah perlekatan yang rendah didekat puncak alveolaris atas pada garis tengah. Pada gigi geligi sulung, frenulum labii sering terlihat melekat pada processus alveolaris diantara gigi incisivus sentralrahang atas.

Dengan pertumbuhan dento-alveolar yang normal, processus alveolaris rahang atas akan 
bertumbuh kebawah dan daerah perlekatan frenulum labial akan memanjang kebawah sehingga berada diantara gigi incisivus kanan dan kiri atas. Akibatnya, akan terbentuk celah antara gigi incisivus kanan dan kiri atas yang disebut diastema.

\section{g. Kebiasaan buruk}

Dalam pertumbuhannya anak-anak sering melakukan berbagai macam kebiasaan buruk antara lain menghisap jempol, menjulurkan lidah, menggigit kuku, bruxism dan lain-lain. Kebisaan pada gigi geligi apabila dilakukan secara berkala dan berkelanjutan maka dapat mengakibatkan kelainan pada gigi. (Pratama, 2018)

\section{Kebiasaan Menghisap Jempol}

Menurut beberapa ahli pengertian kebiasaan diartikan sebagai perilaku yang diulang ulang. Adapula sebagian ahli yang mengartikan anak yang sering melakukan kebiasaan tersebut biasanya justru tidak sadar bahwa ia melakukannya. Tapi berbeda dengan orang-orang disekitarnya seperti orang tua atau saudaranya, mereka terkadang merasa terganggu dengan kebiasaan buruk anak tersebut. (Hidayah, 2019)

Adapun pengertian dari menghisap jempol adalah suatu cara aktivitas rutin yang dianggap normal dari seorang anak kecil usia balita yang memegang peranan penting bagi pertumbuhan dirinya Kebiasaan ini dimulai pada masa awal anak-anak, segera terlihat dalam waktu yang tidakterlalu lama sesudah anak tersebut lahir. Dimana biasanya disamping menetek pada ibunya, dan apabila air susu sang ibu tidak mencukupi, atau aktifitas ibunya dalam kehidupannya, maka menghisap jempol merupakan alternatif lain yang harus dilakukan. (Goenharto, dkk, 2016)

Faktor-faktor yang menyebabkan anak menghisap jempol:

1. Bayi kurang puas menghisap susu dari ibu.

"Kebutuhan menghisap bayi ketika meyusu berbeda-beda pada setiap bayi" lama menyusui berbeda pada antara bayi dan satu dan yang lain. Contohnya ada bayi yang sudah puas menyusu selama 20 menit, namun ada yang baru merasa puas setelah 40 menit. Selain itu, jarak waktu menyusui juga bisa berpengaruh. Bayi yang setiap 3 jam sekali diberi minum, misalnya kebutuhan menghisapnya akan lebih sedikit ketimbang bayi yang diberi minum 4 jam sekali. "Jadi makin sering bayi diberi kesempatan menyusu maka semakin sering pula bayi dapat memenuhi kebutuhan menghisapnya," lanjutnya. Beberapa pakar pun mengatakan, bayi yang menyusu ASI akan lebih jarang menghisap jempol ketimbang yang menyusu dari botol.

Terkadang pula ASI dari ibu yang keluar sedikit dikarenakan karena ibu sakit atau ada ada hal lain seperti puting masuk ke dalam, dll. Selain itu adapula ibu yang terlalu sibuk bekeja sehingga tidak sempat meyusui anaknya denga puas, dan takut payudaranya jelek apabila dia menyusui anaknya. Sebagai gantinya bayi diberi botol susu yang mirip dengan bentuk payudara ibunya. Akan tetapi ada bayi yang tidak menyukai, terlebih kalau dotnya tidak sesuai, lubang dot terlalu besar ataupun kecil. Selain itu menggunakan dot berbeda dengan menyusu langsung dari payudara ibu karena tidak menciptakan ikatan perasaan antara ibu dan anaknya secara langsung, apabila bayi merasa tidak puas dengan dot susunya, dia akan mecari kenikmatan sendiri, dimana yang paling mudah ialah jempol. (Goenharto, dkk, 2016)

Faktor emosi juga bisa menyebabkan anak melakukan kebiasaan jelek. Menghisap jempol saat bayi merasa lelah, stress dan lapar merupakan hal yang normal. Anak kecil yang merasa lapar kemudian tidak diperhatikan, biasanya akan menghisap jempolnya. Selain itu anak yang bermain terlalu capek, marah dikarenakan keinginannya tak tercapai, rasa kesepian karena tidak ada yang menemani, rasa bosan terhadap mainanmainannya, maka biasanya menghisap jempol merupakan alternative untuk mengekspresikan emosinya tersebut.( Guide, 2016 )

2. Faktor kasih sayang orang tua

Faktor kasih sayang orang tua juga sangat penting, karena biasanya anak yang kurang mendapatkan kasih sayang orang tua yang 
dikarenakan karena orang tua terlalu sibuk bekerja ataupun karena masalah keluarga lainnya, dapat mengakibatkan anak mencari perhatian lain, seperti halnya melakukan kebiasaan buruk. ( Putri, 2010 )

\section{Faktor kebebasan bergerak dari anak}

Setiap anak memiliki kesenangan yang berbedabeda, seperti contoh ada anak yang suka bermain diluar rumah, apabila anak tersebut dihambat maka mereka akan mecari jalan keluar sendiri. Anakyang biasa dikurung didalam rumah dan tidak diberi kebebasan biasanya akan melakukan kebiasaan jelek.

\section{Akibat Kebiasaan Menghisap jempol}

1. Akibat kebiasaan menghisap jempol pada gigi anterior

Gigitan terbuka anterior didefinisikan sebagai tidak adanya tumpang gigit dari arah vertical antara gigi-geligi anterior atas dan bawah pada saat oklusi sentrik yang dikenal sebagai tumpang gigit insisivus negatif . (Zen, 2014). Gigitan terbuka bagian depan merupakan salah satu maloklusi yang sering terjad pada anak-anak. Maloklusi ini dapat terjadi pada gigi susu maupun pada gigi tetap dan dapat mengenai satu gigi atau lebih. Walaupun hampir sebagian besar anak-anak normal melakukan kebiasaan menghisap non-nutrisif, dalam hal ini kebiasaan menghisap jempol yang berkepanjangan dapat menyebabkan maloklusi.

Apabila gerakan menghisap amat kuat maka pipi juga memberi tekanan kearah dalam, sehingga bentuk rahang menjadi tidak normal. Seperti yang telah diketahui, kebiasaan menghisap selama fase gigi sulung mempunyai sedikit efek jangka panjang, akan tetapi apabila kebiasaan buruk ini terus berlangsung sampai gigi permanen mulai erupsi, maka dapat terjadi maloklusi yang ditanda dengan adanya kelainan pada gigi-geligi berupa anterior open bite (gigitan terbuka anterior), pergerakan gigi incisivus yang dapat menyebabkan bertambahnya over jet pada gigi anterior.

Jika gigi geligi rahang atas dan rahang bawah pada bagian posterior berkontak satu sama lain tetapi bagian anterior tidak berkontak, maka relasi rahang seperti ini dapat disebut dengan gigitan terbuka anterior (gambar 1)

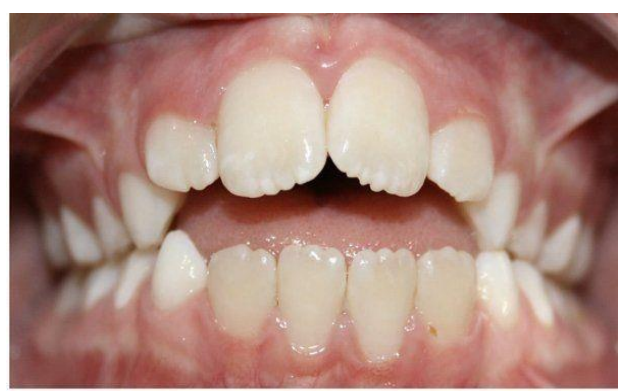

Gambar 1. Anterior open bite (gigitan terbuka anterior)

Gigitan terbuka anterior yang berhubungan dengan kebiasaan menghisap jempol muncul dari suatu kombinasi gangguan erupsi gigi incisivus yang normal dengan adanya erupsi bebas dari gigi posterior, yaitu terhalangnya erupsi gigi anterior karena tekanan jari sehingga gigi posterior dapat bererupsi secara bebas. Apabila jempol atau jari kaki lainnya ditempatkan diantara gigi anterior, maka rahang bawah akn menampung atau menahan jari tersebut. Jempol yang ditempatkan dengan cara demikian menghalangi erupsi gigi anterior secara bersamaan, hal tersebut mengubah keseimbangan gigi posterior secara vertical dan akibatnya terjadi erupsi bebas dari gigi posterior. Posisi erupsi dari gigi posterior ini mengakibatkan gigitan terbuka anterior. Gigi terbuka anterior dapat juga disebabkan karena adanya intrusi gigi incisivus, tetapi hal ini jarang terjadi.(Astrid, 2020)

Menghisap jempol dapat menyebabkan meningkatnya overjet karena terjadi pergerakan gigi geligi anterior. Pergeseran atau pergerakan gigi kearah faciolingual tergantung dari posisi jempol didalam mulut. Biasanya posisi dari jari tersebut menekan permukaan lingual dari gigi incisivus rahang atas dan permukaan labial dari gigi incisivus rahang bawah. Anak yang aktif menghisap jempol dapat mengakibatkan terjadinya pergeseran gigi incisivus rahang atas kearah labial dan pergeseran gigi incisivus rahang bawah kearah lingual. Hal ini 
yang dapat menyebabkan bertambahnya overjet (tergantung pula dari kekuatan tekanannya pada gigi).

2. Akibat kebiasaan menghisap jempol pada gigi posterior

Pada gigi posterior dapat terjadi gigitan silang posterior (posterior cross bite). Penyebab utama terjadinya gigitan silang posterior pada gigi sulung adalah karena terjadi penyempitan lengkungrahang atas. Penyempitan lengkung ini sering diakibatkan oleh karena kebiasaan menghisap jempol yang aktif walaupun terdapat beberapa kasus dimana penyebab dari gigitan silang gigi posterior ini tidak dapat ditentukan. Dalam hal ini penyempitan lengkung rahang atas dapat terjadi karena adanya perubahan keseimbangan antara otot-otot rongga mulut dengan lidah. Jika jempol ditempatkan di antara gigi atas dan gigi bawah, lidah diturunkan, sehingga menurunkan tekanan yang diberikan oleh lidah terhadap aspek lingual gigi posterior rahang atas. Otot-otot seperti musculus orbicularis oris dan musculus buccinator meneruskan tekanan pada permukaan gigi rahang atas, sedangkan lidahtidak dapat mengimbangi tekanan tersebut sehingga terjadi gigitan silang posterior. (Giri, 2017)

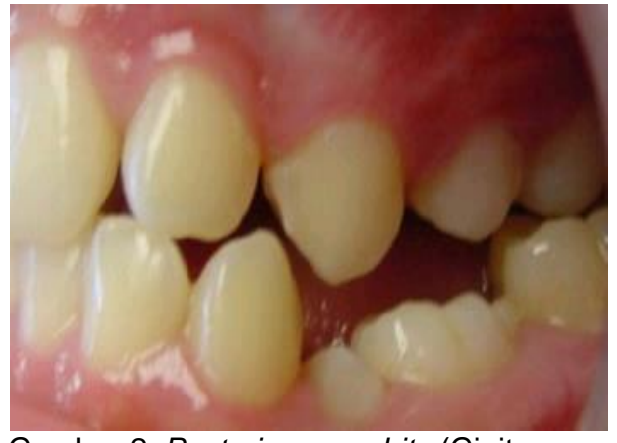

Gambar 2 Posterior cross bite (Gigitan silang posterior)

Kebiasaan, sebagian besar merupakan suatu tahapan dari proses perkembangan yang normal dan tidak perlu terlalu dikhawatirkan. Suatu hal yang menarik adalah kebiasaan buruk tersebut timbul lebih dari satu macam pada anak. Kebiasaan menghisap jempol lebih banyak ditemui dari pada kebiasaan menghisap jari yang lain. Hal ini diduga karena anggapan anak-anak bahwa jempol lebih "enak" dari pada jari tangan yang lain. Tapi ada juga dugaan lain yaitu karena jempol lebih mudah dijangkau oleh mulut. Sebagian besar anak yang mempunyai kebiasaan menghisap jempol tangannya berusia sekitar 2 tahun. (Elianora, 2014)

Sebagian besar kebiasaan buruk yang dilakukan pada masa anak-anak akan menghilang seiring dengan pertambahan usia anak. Bila orang tua tidak bersikap berlebihan pada kebiasaan buruk yang dimiliki anaknya, si anak akhirnya akan menghentikan kebiasaannya tersebut dengan sendirinya. Kebiasaan memerlukan waktu untuk berkembang, demikian pula untuk menghentikannya. (Elianora, 2014)

Sebelum menghentikan kebiasaan anak tersebut, orang tua harus melakukan intervensi dengan cara:

1. Mengetahui penyebab. Sebelum memulai pengobatan, kebiasaan anak sehari-hari harus diketahui termasuk cara anak beradaptasi terhadap lingkungan di sekitarnya. Bila faktor pencetus emosional dan psikologis telah ditemukan maka terapi anak siap untuk dimulai.

2. Menguatkan anak. Terapi harus dimulai dengan keikutsertaan anak, kerjasama, dan yang paling penting ketertarikan untuk menghentikan kebiasaan tersebut. Orangtua diingatkan untuk tidak memberikan hukuman pada anak, karena anak akan semakin menolak untuk menghentikan kebiasaan buruknya ini. (Senjaya, 2012) Apabila kebiasaan buruk anak terus bertahan, semakin buruk, atau mengganggu orang lain, dapat mencoba dengan cara-cara berikut ini:

1. Perawatan psikologi :

Menjelaskan ke anak dengan jelas dan perlahan bahwa anda tidak suka kebiasaan buruknya itu. Jelaskan juga kepada anak mengapa anda tidak menyukai kebiasaan buruknya itu. Ucapkan dengan kalimat seperti "Ayah/lbu tidak suka bila kamu menggigit kukumu. Kebiasaan itu adalah kebiasaan yang tidak baik dan jorok. Dapatkah kamu menghentikan kebiasaanmu itu?" Ingat bila anak anda tetap melakukan kebiasaannya itu jangan mengejek atau "menguliahi" anak anda. 
Hukuman, ejekan, atau kritik dapat menyebabkan kebiasaan anak semakin buruk. Minta anak anda untuk ikut terlibat langsung proses penghentian kebiasaannya itu. Beritahu langsung kepada anak anda apa yang kira-kira dapat menghentikan kebiasaannya tersebut. Beritahu dengan jelas dan perilaku positif yang anda harapkan dari anak anda. ( Goenharto, dkk, 2016)

Kebiasaan buruk pada anak mungkin akan menjadi masalah yang lebih serius. Contohnya, anak yang sering menghisap jempol tangannya mungkin sebenarnya merasa "tertekan" secara psikologis. Bila kebiasaan buruk anak ini terus berkembang dan dapat membahayakan anak tersebut, maka anda harus waspada karena kebiasaan buruk ini dapat mempengaruh perkembangan gigi saat anak tumbuh dewasa. Kebanyakan kebiasaan buruk pada anak tidak membutuhkan bantuan profesional. Akan tetapi apabila kebiasaan tersebut mulai menggangu fungsi fisik atau sosialnya atau kebiasaannya tersebut terus bertahan setelah anda mencoba menghentikannya dengan langkah-langkah seperti yang telah disebutkan di atas, mungkin kebiasaannya tersebut disebabkan oleh suatu keadaan fisik atau psikologis yang lebih serius. Sebaiknya, anda harus segera berkonsultasi dengan dokter. ( Elianora, 2015)

Memberikan penjelasan kepada anak dengan halus tentang dampak menghisap jempol, misalnya kotoran yang ada pada kuku akan masuk ke mulut dan menyebabkan sakit perut. Upayakan anak anda sadar dan tahu betul mengapa ia harus menghentikan kebiasaannya tersebut. Kemudian jangan biarkan anak anda melamun atau berkhayal, berikan kesibukan dengan menemaninya bermain atau membacakan dongeng sebelum ia tidur Jangan sekali-kali melarang anak secara langsung dengan keras misalnya mencabut jempol yang sedang dihisap secara kasar atau mengejek dan memperolok- olok. Hal ini akan menggangu perkembangan jiwanya. Apabila kebiasaan tersebut disertai kebiasaan lain misalnya menarik-narik ujung rambut, memegang-megang daun telinga, menarik kerah baju, ujung bantal dan lain-lain maka usaha pertama ialah menghilangkan kebiasaan sekunder tersebut misalnya, rambutnya dipotong pendek, beri baju kaos tanpa kerah, tidur tanpa bantal dan lainlain sehingga kebiasaan primernya tersebut akan berhenti. (Guide, 2016)

Menghisap jempol juga bisa dihilangkan dengan cara/ terapi reward system (sistem berhadiah). Cara ini dilakukan dengan membuat perjanjian antara dokter gigi dan anak antara orang tua dan anak. Perjanjian dapat berupa pemberian hadiah pada anak apabila kebiasaan telah dihentikan pada periode tertentu. Hadiah yang diberikan tidak perlu yang luar biasa tetapi dapat berupa barang misalnya stiker, buku cerita dan lainlain yang dapat memotivasi anak untuk menghentikan kebiasaan tersebut atau berupa ajakan untuk rekreasi sesuai keinginanya. Keterlibatan anak dalam hal ini menunjang keberhasilan cara/ terapi yang dilakukan. Pada waktu-waktu tertentu dapat pula diberikan hadiah berupa pujian secaralisan. (Noya, 2019)

\section{Perawatan ekstra oral}

Bila anak anda belum bisa menerima penjelasan, maka dapat dicoba dengan cara reminder terapi. Terapi ini merupakan terapi untuk mengontrol atau mengingatkan anak untuk tidak menghisap jempol. Cara ini digunakan untuk anak yang ingin menghentikan kebiasaan ini tetapi masih memerlukan bantuan untuk menolong agar kebiasaan itu benar-benar berhenti. Terapi ini digolongkan pada perawatan ekstra oral misalnya mengolesi permukaan jempol dengan bahan yang tidak enak (pahit/pedas), pembalut elastis, sarung tangan sebagai peringatan agar tidak memasukkan jempol ke dalam mulut, penggunaan bahan yang tidak enak (pahit/pedas) seperti kina, lada, minyak kayu putih dan lain-lain yang diulaskan pada jari untuk mengingatkan anak agar dapat menahan diri supaya tidak menghisap jempol, kemudian dapat juga dengan melepaskan jempol anak dari dalam mulut setiap menemukan anak menghisap jempolnya kemudian menggantinya dengan sesuatu 
yang dapat dikunyah. Orang tua bisa juga meminta bantuan dokter gigi untuk memperlihatkan foto-foto yang jelas tentang akibat dari kebiasaan menghisap jempol agar anak akan jera sendiri dan mencoba untuk tidak menghisap jempol lagi.

Kendala dari terapi ini khususnya pada penggunaan plester atau larutan pahit/pedas adalah kadang-kadang dirasakan kurang efektif karena anak-anak menganggapnya sebagai suatu hukuman. Hal penting yang harus diingat adalah jangan menghukum anak. Menakut-nakuti atau memberikan rasa tidak nyaman pada anak, bukanlah hal yang dianjurkan. (Hidayani, 2019)

\section{Perawatan intra oral}

\section{a. Palatal Crib}

Palatal crib adalah alat yang umum digunakan untuk membantu mengurangi kebiasaan menghisap jempol. Alat ini merupakan alat cekat digunakan untuk mengoreksi gigitan terbuka anterior tetapi tidak untuk gigitan terbalik posterior. Dapat juga digunakan sebagai retainer mengikuti pelebaran lengkung rahang atas. Saat pemasangan palatal crib sebaiknya orang tua dan anak diberitahu tentang beberapa efek yang muncul setelah alat tersebut dipasang. Pola makan, berbicara dan tidur mungkin akan mengalami perubahan pada hari-hari pertama pemakaian. Perubahan ini biasanya akan hilang dalam waktu 3 hari sampai dengan 2 minggu.

Alat ini bersifat pasif tetapi akan terbenam kedalam jaringan palatum sehingga bila ada tekanan lidah atau jari-jari yang mungkin tanpa sengaja dimasukkan anak yang memakai alat ini dalam mulutnya, maka anak akan merasa sakit pada jari. Perpindahan alat tersebut dapat menyebabkan infeksi, rasa tidak enak dan menambah kecemasan Pelepasan alat yang terbenam ini sering memerlukan anastesi local dan kemungkinan insisi mukosa yang menutupi. ( Utami N, Suwelo I S, 2015)

\section{b. Quad Helix}

Quad helix adalah alat untuk mengoreksi penyempitan lengkung rahang atas bilateral. Seperti halnya dengan palatal crib, Quad helix juga merupakan alat yang dapat membantu mengurangi kebiasaan menghisap jempol. Quad helix sebagai alat cekat yang ditempatkan pada rahang atas dimana alat ini dipakaikan pada anak yang frekuensi menghisap jempolnya terlalu sering.

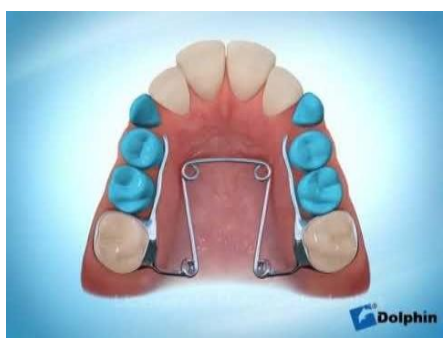

Gambar 3. Palatal crib

Alat ini dirancang untuk memperluas ruang dalam mulut, alat cekatini akan disesuaikan sesuai bentuk rahang penderita. Seperti halnya padaalat cekat palatal crib, quad helix juga memerlukan penyesuaian waktu dan mempengaruhi cara berbicara untuk sementara waktu. Dibutuhkan perawatan khusus dalam hal penyikatan alat ini, yaitu benar-benar harus disikat setiap selesai makan. Jika alat ini menimbulkan bekas dilidah sebaiknya tidak usah khawatir karena hal ini normal terjadi. Hindari menggunakan jari atau lidah pada alat ini karena dapat mempengaruhi perawatan dan merusak alat. (Fithriyah R E, 2016)

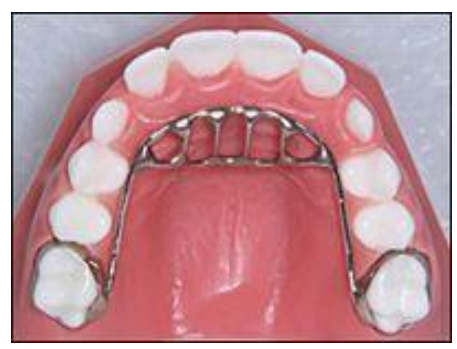

Gambar 4. Quad helix

\section{Simpulan}

Kebiasaan buruk menghisap jempol sebaiknya ditanggulangi sejak dini agar tidak terjadi maloklusi yang tidak diinginkan. Upaya menghentikan kebiasaan buruk dimulai dari perawatan psikologi dengan melakukan pendekatan dan pemberian nasehat terhadap anak, dapat pula 
dilakukan tindakan ekstra oral dengan pemberian rasa yang tidak biasa pada jempol, namun apabila kurang berhasil dapat dilakukan perawatan intra oral yaitu dengan alat palatal crib dan quad helix. Tidak semua kebiasaan buruk menghisap jempol dapat menyebabkan maloklusi, dan bergantung pada intensitas, frekuensi, dan lamanya kebiasaan itu dilakukan. Maloklusi akibat menghisap jempol mungkin dapat menjadi normal kembali tanpa harus dirawat,setelah kebiasaan itu ditinggalkan.

\section{Saran}

Diharapkan adanya perhatian khusus bagi anak yang sedang dalam masa tumbuh kembang dimana sering melakukan kebiasaan buruk. Karena kebiasaanini dapat menganggu masa pertumbuhan dan perkembangan mereka, dan apabila dibiarkan begitu saja akan sangat sulit untuk dihentikan.

\section{Daftar Pustaka}

Aufar Rafif Adha, M., Wibowo, D., \& Indah Rasyid N. (2019). Gambaran Tingkat Keparahan Maloklusi Menggunakan Handicapping Malocclusion Assessment Record (Hmar) Pada Siswa Sdn Gambut 10. Jurnal Kedokteran Gigi, 3(1), 2. https:_//ppjp._ulm. ac.id/journals/index.php/ dnt/article/download/884/846. Diakses pada tanggal 05 Oktober 2020

Astrid, N. (2020). Dampak buruk akibat menghisap ibu jari bagi perkembangan gigi dan mulut https: //dental.id/dampak-buruk-akibatmenghisap - ibu - jari- bagi - perkembangan - gigi - dan - mulut/. Diakses pada tanggal 07 Oktober 2020

Dentalosophy. (2020). Apa itu persistensi gigi ? Apa penyebab dan bagaimana cara penanganannya? https: //dentalosophy. id/ education/ apa-itu- persistensi-gigi-apapenyebab-dan-bagaimana-cara-

penangannya. Diakses pada tanggal 07 Oktober 2020

Dewi, N. I. (2017). Menghisap Jempol dan Cara Menguranginya. 5-7. https:// www. Childrencafe. com/ menghisap - jempol - dan - cara menguranginya/. Diakses pada tanggal 07 Oktober 2020

Elianora, D. (2018). Pemeriksaan Lengkap Kebiasaan Buruk Mengisap lbu Jari (Thumb Sucking) (Laporan Kasus). B-Dent, Jurnal Kedokteran Gigi Universitas Baiturrahmah,
1(2), 102-

111.https://doi.org/10.33854/ibdibd.4

Diakses pada tanggal 08 Oktober 2020

Elianora, D. (2015). Perawatan kebiasaan buruk menghisap ibu jari dengan alat orto trainer. $C$ Dent, 7(1), 745-753. http: //www. jurnal. unsyiah. ac.id/ CDJ/ article/download/ 10431/8209. Diakses pada tanggal 26 Desember 2020

Fidya. (2018). Anatomi gigi \& mulut. Malang : UB Press.

Fithriyah, R. El. (2017). Kombinasi penggunaan quadhelix dan tanggul gigitan posterior pada perawatan crossbite anterior. Majalah Kedokteran Gigi Indonesia, 2(1), 47. https://doi.org/10.22146/majkedgiind.12316. Diakses pada tanggal 25 Desember 2020

Gambar 2.1. Anterior open bite. http : //images.google.co.id/images? q=quad+helix \&hl=id\&client=firefox $-\mathrm{a} \&$ channel=s \&rls=org.mozilla:en-US: official \&um=1 \&ie=UTF8\&ei=nF0ySWfH4ylkAXh7lyg $\mathrm{Cg} \& \mathrm{sa}=\mathrm{X} \& \mathrm{oi}=$ image_result_group \& resnum $=4 \& \mathrm{ct}=$ title. Diakses pada tanggal 09 Oktober 2019

Gambar 2.2. Posterior Cross Bite. http: //ojs. lib. unair. ac.id/ index.php/dj/article/ view File/ 732/ 728. Diakses pada tanggal 09 Oktober 2019

Gambar 2. 3. Palatal Crib. https://www.google. $\mathrm{com} /$ url?sa $=$ i\&url $=$ https $\%$ 3A\%2F\%2Fwww.pinterest.com\%2Fpin\%2F48 9133209510920040\%2F\&psig=AOvVaw17G0 uOVhtrC1qr6A_7B65r\&ust=16114964698640 $00 \&$ source $=$ images $\& c d=v f e \& v e d=$ 0CAkQjhxqFwoTCLCF38vks -4CFQ

AAAAAdAAAAABAD. Diakses pada tanggal 25 Desember 2020

Gambar 2. 4. Quad Helix. https: //www.google. com/url?sa $=$ i\&url $=$ https \%3A\%2F\%2Fwww.pinterest.com\%2Fpin\%2F $123989795961307613 \% 2 F \& p s i g=A O v V a w 19$ okq5kW1 te4lae4H5kXQ\&ust=161149663032 $5000 \&$ source $=$ images \&cd $=$ vfe\&ved $=0 C A k Q j h$ xqFwoTCODwlqnls-4CFQAAAAA dAAAAABAJ. Diakses pada tanggal 25 Desember 2020

Giri, P. (2017). Efek buruk dari kebiasaan menghisap jempol kaki pada anak. https: //simdos.unud.ac.Id/uploads/file penelitian dir /e1dge 7f9f8ee6dc1a696a81fb2eacgee. pdf. Diakses pada tanggal 05 Oktober 2020

Goenharto, S., Rusdiana, E., \& Nurlaili, Y. (2016). Tatalaksana Mengatasi Kebiasaan Buruk Menghisap Jari. Jurnal Persatuan Dokter Gigi Indonesia, 65(2), 48-54. 
https://jurnal.pdgi.or.id/index.php/ jpdgi/ article/ download/ 143/134. Diakses pada tanggal 11 Oktober 2020

Guide, P. (2016). Growing Up: Usia 3-4 Tahun. PT Tiga Serangkai Pustaka Mandiri.

Hatta, R. (2011). Laporan Embriologi Gigi. https://www.academia. edu/ 6056802/ EMBRIOLOGI_GIGI. Diakses pada tanggal 11 Oktober 2020

Hidayani, T. A. (2019). Efek Kebiasaan Buruk Mengisap Jari pada Balita dan Anak - anak. 47. https://sardjito.co.id/2019/06/04/efekkebiasaan-buruk- menghisap-jari-pada-balitadan-anak-anak/. Diakses pada 05 Oktober 2020

Noya. (2019). Begini cara menghentikan kebiasaan menghisap jempol pada anak. https:// www. alodokter. com/ begini - cara - menghentikan -kebiasaan - mengisap - jempol - pada anak. Diakses pada 27 Desember 2020

Pratama AG. (2018). Faktor-faktor yang Mempengaruhi Pertumbuhan dan Perkembangan Gigi.

https://www.dictio.id/t/faktor-apa-saja-yangmempengaruhi - pertumbuhan - dan perkembangan - gigi - manusia/ 16583. Diakses pada tanggal 07 Oktober 2020

Pratiwi, Y. (2013). 45 Masalah \& Solusi Penyakit Gigi dan Mulut. Andi Offset. Putri, M. dkk. (2010). Tips praktis menangani perilaku anak. PT Citra Aditya Bakti.
Riset Kesehatan Dasar (Riskesdas). (2018). Departemen Kesehatan Republik Indonesia. Badan Litbangkes, Depkes RI.

Savitri, E. (2020). Pertumbuhan \& Perkembangan gigi Geligi. http: //ebeltim. blogspot. com/ 2012/ 02/ pertumbuhan-perkembangan-gigi-geligi. $\mathrm{html} ? \mathrm{~m}=1$. Diakses pada tanggal 07 Oktober 2020

Senjaya, A. A. (2012). Kebiasaan Buruk yang Dapat Merubah Bentuk Wajah Asep Arifin Senjaya 1. Dosen Jurusan Kesehatan Gigi Poltekkes Denpasar, 9. http:// www.Poltekkesdenpasar.ac.id/ files/ JSH/ V9N1/ Asep Arifin Senjaya $1 \mathrm{JSH}$ V9N1.pdf. Diakses pada tanggal 26 Desember 2020

Utami, n. (2003). Pemasangan palatal cn . Pada anak usia 5tahun untuk menghilangkan kebiasaan jari dan memperbaiki oklusi (laporan kasus) Kedokteran gigi, 907-912. Https://www.researchgate.net/publication/307 838002 pemasangan_pal atal_crib_pada_anak_usia_5_tahun_untuk m enghilangkan kebiasaan menghisap jari $\bar{d}$ da n_memperbaiki_oklusi_laporan_kasus/fulltext/ 57d1e48708ae0c0081e057c4/pemasanganpalatal-crib-pada-anak-usia-5-. Diakses pada tanggal 26 desember 2020

Zen, Y. (2014). Perawatan Ortodontik Gigitan Terbuka Anterior. Majalah Kedokteran Gigi Indonesia, 21(1), 1.https://doi.org/10.22146/ majkedgiind. 8304. Diakses pada tanggal 06 Oktober 2020 